\title{
POLITIK IDENTITAS MASYARAKAT TENGGER DALAM MEMPERTAHANKAN SISTEM KEBUDAYAAN DARI HEGEMONI ISLAM DAN KEKUASAAN
}

\author{
Ali Maksum \\ UIN Sunan Ampel Surabaya \\ e-mail: alimaksum11@yahoo.co.id
}

\begin{abstract}
This article explores the dynamic of Tengger communities life in order to defend its culture with regard to the expansion of Islam and the power of Indonesian government. The research were conducted in two villages, Ngadisari and Sapikerep, Probolinggo. Using the perspective of representation theory, this study elaborate more detail about the strategy of the Tengger people in representing their identity in the midst of the dynamics of the changing time. The dynamics dialectic between the Tengger and power (Islam) have brought out two important propositions. First, because of the strong tradition and culture Tengger systems, both Hindu and Islamic ideology interpreted as a cultural system that only symbolically attached to the Tengger. Second, although impressed syncretic, in fact, Islam and Hinduism also established world view Tengger substantive and culturally. The second view is as commonly as Islam in Java, "Javanese Islam" behind its character as if syncretic. However, it shows "substantial Islam" because it is based on religious traditions of Sufism.
\end{abstract}

Artikel ini mengeksplorasi dinamika masyarakat Tengger dalam mempertahankan sistem kebudayaan dari ekspansi Islam dan kekuasaan pemerintah Indonesia. Penelitian dengan mengambil lokus di dua desa, Ngadisari dan Sapikerep, Probolinggo. Dengan menggunakan perspektif teori representasi, penelitian ini hendak mengelaborasi strategi masyarakat Tengger dalam merepresentasi identitas diri mereka di tengah-tengah dinamika perubahan zaman. Dinamika dialektika antara Tengger dengan kekuasaan (Islam) melahirkan dua proposisi penting. 
Pertama, karena kuatnya tradisi dan sistem kebudayaan masyarakat Tengger, baik ideologi Hindu maupun Islam, dimaknai sebagai sistem kebudayaan yang tidak ubahnya hanya melekat secara simbolik bagi masyarakat Tengger. Kedua, meskipun terkesan sinkretis, sesungguhnya Islam maupun Hindu juga membentuk world view masyarakat Tengger secara subtantif dan kultural. Pandangan kedua tidak ubahnya seperti sistem keagamaan masyarakat Jawa pada umumnya yang menganut agama Islam. "Islam Jawa" di balik wataknya seolah-olah sinkretis, namun sesungguhnya tetap menunjukkan "Islam subtansial" karena berbasis tradisi keagamaan tasawuf.

Keywords: identity, cultural system, Islam, power

\section{Pendahuluan}

Masyarakat Tengger, seperti dikatakan Hefner, memiliki keunikan di antara masyarakat pegunungan di Indonesia, bahkan di Asia Tenggara. Selain memiliki historiografi sejarah yang panjang, Tengger dikenal memiliki keteguhan dalam mempertahankan nilai-nilai, tradisi, dan kebudayaan, di tengah arus perubahan zaman (Hefner, 1999: xxii). Menurut beberapa versi, komunitas Tengger berasal dari pelarian Majapahit di akhir periode kekuasaannya yang kalah oleh kekuasaan Islam Demak. Tetapi, menurut pendapat lainnya, entitas suku Tengger telah mendiami daerah sekitar Gunung Bromo sebelum era Majapahit.

Pergulatan suku Tengger dengan tradisi dan kebudayaan mereka terancam karena faktor dominasi kekuasaan Islam, baik Demak, Mataram, dan dinamika Islam di era modern. Selain itu, rentetan kekuasaan kolonialisme Eropa, khususnya Belanda juga tidak kalah penting dalam mengubah tradisi dan kebudayaan masyarakat Tengger. Di era kekuasaan Islam klasik, ekspansi Demak ke wilayah Pasuruan terus merambah hingga kerajaan terakhir Hindu, yakni Blambangan, Banyuwangi. Menurut Hefner (1999: 49-55), wilayah Tengger merupakan benteng terakhir komunitas Hindu untuk menyelamatkan diri, selain wilayah Bali. Pendapat Hefner ini dikuatkan oleh Pigeaud (1962: 244), demi mempertahankan tradisi dan budaya, komunitas Tengger banyak mendapat hambatan dari kekuasaan Islam. Sementara itu, Belanda membuat kebijakan dalam bidang pertanian yang juga turut membentuk pola-pola kehidupan masyarakat, khususnya di bidang ekonomi.

Di era Indonesia modern, pemerintah Orde Baru dengan kekuasaan otoriternya, memaksa suku Tengger untuk mengikuti satu di antara lima agama resmi yang diakui pemerintah. Dalam rangka merepresentasikan identitas tradisi 
dan kebudayaan Tengger, masyarakat Tengger terpaksa harus mengikuti Hindu sebagai agama mereka. Perdebatan tentang apakah suku Tengger sesungguhnya beragama Hindu atau agama lokal, yakni agama Tengger sendiri, masih menjadi perdebatan panjang. Selain itu, serbuan Islam telah merambah di kalangan masyarakat Tengger, khususnya yang tinggal di dataran sedang dan rendah pegunungan Bromo. Kebijakan Belanda yang mempekerjakan orang-orang Madura dan Jawa yang beragama Islam lambat laun mempengaruhi sebagian masyarakat Tengger yang tinggal di dataran sedang dan rendah.

Terlepas dari dinamika di atas, realitas masyarakat Tengger dengan identitas nilai-nilai lokal, tradisi, dan sistem budaya yang masih kuat hingga era modern ini menjadi mozaik yang menarik untuk dianalisis. Relasi antara kekuasaan, Islam, dan suku Tengger menjadi fakta menarik tersendiri. Di tengah gempuran perubahan, masyarakat Tengger terbukti masih kuat dalam mempertahankan tradisi dan budaya mereka. Meskipun telah memeluk Islam, suku Tengger masih tetap mempertahankan nilai-nilai budaya lokal. Bagaimana sesungguhnya yang terjadi dalam proses dialektika antara Islam, Kekuasaan, dan Tengger ini? Bagaimana strategi kebudayaan yang dilakukan masyarakat Tengger untuk merepresentasikan eksistensi diri mereka di dalam dinamika perubahan dan pengaruh hegemoni (kekuasaan) Islam dan dominasi kekuasaan politik pemerintah Orde Baru? Inilah yang menjadi arah dari tulisan ini.

\section{Metode Penelitian}

Penelitian ini menggunakan metode deskriptif kualitatif. Penelitian deskriptif kualitatif bertujuan mengggambarkan suatu fenomena tertentu yang bertumpu pada prosedur-prosedur penelitian yang menghasilkan data deskriptif berupa kata-kata tertulis atau lisan dari orang-orang dan perilaku secara holistik. Teknik pengambilan data menggunakan tiga teknik, yaitu teknik partisipan, wawancara, dan dokumentasi.

\section{Historitas "Agama” Orang Tengger}

Sebelum Orde Baru berkuasa di Indonesia, pasca tragedi G 30 S 1965, agama orang Tengger kerap disebut Budo. Istilah Budo sendiri sebenarnya dikemukakan oleh orang Islam dari daratan bawah (ngare). Istilah Budo untuk menandai bahwa orang Tengger bukanlah pemeluk agama Islam. Bahkan dari kalangan Islam di bawah, istilah Budo seringkali disepadankan dengan bentuk-bentuk kekafiran. 
Tatkala orang Islam dari ngare melekatkan konotasi Budo tersebut, orang Tengger (wong gunung) tidak menampik sebutan Budo tersebut. Istilah Budo diterimanya, sekaligus untuk membangun definisi atas sistem kepercayaan mereka. Namun konotasi Budo sebagaimana yang dipahami oleh orang Tengger sendiri adalah agama yang telah lama berkembang di Tengger.

Perubahan atas sistem kepercayaan orang Tengger bermula saat pemerintah Orde Baru menjalankan formalisasi agama. Dengan menyandarkan diri pada PNPS Nomor 1 tahun 1965 mengenai kebijakan pengakuan agama oleh negara. Melalui kebijakan ini, negara hanya mengakui lima agama saja, yakni: Islam, Kristen, Katolik, Hindu, dan Budha. Orde Baru memanfaatkan kebijakan warisan Orde Lama ini untuk melakukan kontrol atas kepercayaan yang berkembang di masyarakat. Tujuan pemerintah Orde Baru melakukan sistem kontrol tersebut adalah untuk mendapatkan ketundukan dari rakyat dalam menjalankan berbagai kebijakan nasional secara korporatis.

Dalam catatan yang dituliskan oleh Hefner (1990), kanal-kanal di Pasuruan banyak sekali ditemukan jasad orang Tengger. Kejadian ini menjadi trauma banyak pihak secara nasional. Siapapun yang mendapatkan label komunis bagaikan sedang menghadapi kiamat. Bahkan proses ini terus berlangsung hingga kini. Akibat tragedi berdarah itu, ada trauma yang mendalam dari orang Tengger. Label kafir dan komunis telah menjadi momok baru dalam kehidupan mereka. Beragam cara mereka tempuh untuk terhindar dari stigma itu. Salah satu yang mereka lakukan adalah menjalankan ritual khitanan (sunat). Akibat dianggap kafir oleh orang-orang ngare karena tidak melakukan sunat, akhirnya orang Tengger menjalankan praktik sunat.

Praktik sunat orang Tengger tentu saja berbeda dengan praktik sunat orang Islam pada umumnya. Praktik sunat hanya cukup mengiris kelamin lakilaki, sehingga sekedar mengeluarkan darah. Padahal dalam konsepsi khitan orang Islam harus memotong sebagian kelamin laki-laki. Dengan dijalankannya sunatan ini di Tengger, maka tidak cukup alasan bagi orang orang ngare untuk menuduh orang orang Tengger sesat atau kafir.

Momentum ketakutan yang saat itu sedang melanda seluruh kawasan Tengger ini benar-benar dimanfaatkan oleh Orde Baru. Pada tahun 1969, Kabupaten Probolinggo dipimpin oleh bupati dari kalangan santri (Nahdlatul Ulama). Karena pemerintah pusat mewajibkan kebijakan formalisasi agama, maka Bupati Ishak melakukan peninjauan atas keyakinan orang Tengger. Ia berkunjung ke desa-desa Tengger di kawasan Probolinggo, seperti Sapikerep, Ngadas, Jetak, hingga ke Ngadisari. 
Setiap kepala desa dan pemuka desa ditanya satu per satu. Mereka ditanya apakah agama atau keyakinan orang Tengger.

"Kami ditanya oleh Bupati Ishak, apakah agama atau keyakinan orang Tengger. Ia menyatakan bahwa agama orang Tengger adalah Budo. Lalu kami menjawab bahwa agama orang Tengger memang agama Budo. Kami jelaskan ke Pak Ishak, bahwa agama Budo telah ada sejak nenek moyang kami ada. Mendengar jawaban kami, tampaknya Bupati Ishak memahami keyakinan kami" (Wawancara dengan Wirnoto, pemuka masyarakat Tengger, 20 Oktober 2014).

Dua tahun setelah kedatangan Bupati Probolinggo ke desa-desa Tengger, pada tahun 1971, Departemen Agama, melalui Dirjen Bimas Hindu-Budha juga datang ke kawasan Pegunungan Tengger. Alasan kedatangan mereka adalah ingin melakukan penelitian atas keyakinan orang Tengger. Dari hasil penelitian itu, pada tahun 1971 Departemen Agama menetapkan bahwa keyakinan masyarakat Tengger adalah Budha Mahayana.

Keputusan Departemen Agama itu tampaknya belum final. Pada tahun 1973, Dirjen Bimas Hindu-Budha melakukan inspeksi kembali ke desa-desa di Tengger. Mereka kembali melakukan pengkajian atas keyakinan orang Tengger. Dari hasil inspeksi itu, Departemen Agama memerintahkan kepada Parisada Hindu Dharma Indonesia (PHDI) Jawa Timur, agar memasukkan agama Budha Mahayana dalam keanggotaan PHDI. Akhirnya PHDI Jawa Timur mengeluarkan surat keputusan mengenai persoalan ini. Berdasar Surat Keputusan No. 00/PHB-Jatim/Kept/III/73 tertanggal 6 Maret 1973, agama Budha Mahayana yang ada di Tengger menjadi anggota PHDI Jatim.

Penetapan ini secara serius "memaksa" orang Tengger untuk melakukan permusyawaratan internal. Pada tahun 1973 ini pula para pemuka masyarakat, dukun, dan kepala desa sekawasan Tengger berkumpul di Desa Ngadisari. Mereka memusyawarahkan keyakinan mereka itu termasuk dalam kategori agama sesuai yang dikehendaki oleh pemerintah, yakni menganut salah satu agama formal. Mereka berkumpul di Desa Ngadisari dengan alasan bahwa Alm. Suja'i sebagai Dukun Desa Ngadisari sekaligus menjadi koordinator dukun sekawasan Tengger tinggal di desa tersebut.

Terjadi perdebatan yang sangat panjang di antara para peserta musyawarah. Sebagian besar peserta musyawarah mempercayai bahwa keyakinan orang Tengger termasuk dalam kategori agama Hindu, sementara yang lainnya tetap menolak. Kelompok pemuka Tengger yang menolak agama Hindu ini menghendaki bahwa keyakinan orang Tengger tetap Budo (Tengger), bukan Budha Mahayana. Namun suara-suara mereka itu tampaknya tidak mengubah apapun dari hasil keputusan musyawarah. 
Bahkan tiga tahun kemudian, tepatnya pada tahun 1976, Departemen Agama secara resmi memerintahkan agama Budha Mahayana yang dianut oleh orang Tengger, berubah menjadi agama Hindu. Akhirnya secara resmi pula agama Hindu ditetapkan sebagai agama orang Tengger diletakkan dalam keanggotaan PHDI. Penetapan ini secara simultan juga berlangsung secara hirarkis. Koordinator dukun sekaligus juga menjabat sebagai ketua PHDI di Kabupaten Probolinggo. Alm. Soeja'i selaku koordinator dukun yang menjadi Ketua PHDI Probolinggo juga diwajibkan untuk membentuk struktur kepengurusan PHDI di tingkat kecamatan dan desa-desa di kawasan Tengger. Secara perlahan, terbentuklah struktur kepengurusan PHDI hingga ke desa-desa di kawasan Tengger sampai saat ini.

Keberhasilan menformalisasikan keyakinan orang-orang Tengger ini menjadi ruang yang "absah" bagi pemerintah untuk menjalankan program -program pendidikan agama Hindu. Pada tahun 1979, Kantor Wilayah (Kanwil) Depag Jatim mengirimkan guru agama Hindu dan agama Islam di kawasan Tengger. Sebelumnya, sekolah-sekolah di kawasan Tengger tidak mengenal pendidikan agama. Di sekolah, anak anak Tengger hanya diajarkan pendidikan budi pekerti. "Pengetahuan tentang agama (adat) awalnya hanya diajarkan di masing masing keluarga dan dipraktikkan dalam setiap ritual. Mulai tahun 1979, saat guru-guru agama didatangkan ke Tengger, sekolahsekolah di sini dikenalkan pendidikan agama” (Wawancara dengan Wirnoto, pemuka masyarakat Tengger, 20 Oktober 2014).

\section{Representasi Masyarakat Tengger: Potret Negosiasi Kebudayaan}

Jika dalam bagian sebelumnya, peneliti mengajukan ulasan mengenai perjumpaan orang Tengger dengan agama formal yang diakui oleh negara, maka pada bagian ini ulasan pokoknya adalah strategi orang-orang Tengger mempertahankan nilai-nilai adatnya. Masuknya agama-agama formal memang menjadi fenomena yang tidak terhindarkan. Di samping karena faktor proses interaksi sosial, dalam konteks agama tertentu seperti Hindu memang ada intervensi negara yang terlihat sangat dominan, baik secara langsung maupun tidak langsung. Dinamika ini mau tidak mau membuat masyarakat Tengger harus melakukan proses-proses negosiasi dalam rangka tetap mempertahankan dan merepresentasikan identitas "ke-Tengger-an" mereka.

Negosiasi merupakan strategi "menawar" yang dilakukan oleh masyarakat Tengger untuk tetap dapat menjalankan adatnya di tengah berbagai kekuatan modern yang dalam beberapa hal perjumpaannya dengan adat Tengger 
menjadi sangat mengancam. Namun modernisasi dan tradisionalisme di Tengger berjalan beriringan. Saat berhadapan dengan modernisasi yang kadangkala menguntungkan dan merugikan ini, orang Tengger mengatur siasat sedemikian rupa untuk melangsungkan kehidupan mereka. Strategi negosiasi merupakan cara yang lebih lembut dalam menghadapi kekuatan yang sangat besar di luar dirinya.

Membahas tentang masyarakat Tengger dengan sistem kebudayaan, tradisi, sosial, sistem keagamaan, memang tidak mudah. Selain karena luasnya wilayah (kebudayaan Tengger terbentang luas secara teritorial tercakup di empat kabupaten; Kabupaten Malang, Pasuruan, Probolinggo, dan Lumajang), terdapat faktor lain yang saling mempengaruhi. Penelitian yang dilakukan Hefner juga dirasakannya masih kurang, meskipun telah melakukan riset selama 2 tahun (1978-1980) dan telah mewawancarai sebanyak 342 kepala keluarga (Hefner, 1999: xxii). Hefner mewancarai masyarakat Tengger, baik yang tinggal di dataran rendah pengunungan, dataran sedang, dan dataran tinggi (puncak) Bromo. Semua ini dilakukan dalam rangka memahami secara mendalam tentang kebudayaan masyarakat Tengger.

Dalam studinya, Hefner menggunakan multi perspektif atau multi teori. Sebagai seorang sarjana Barat, Hefner seperti terlihat dalam karyanya menguasai perkembangan teori-teori sosiologi modern (Hefner, 1985 dan 1999). Dalam risetnya, sejak awal Hefner menyadari akan kompleksitas masyarakat modern. Karena itu, teori-teori sosiologi modern Barat yang dibangun pada abad XIX dan awal abad XX tidak cukup menggambarkan dinamika masyarakat modern. Dinamika perkembangan masyarakat modern menunjukkan kompleksitas variabel yang saling mempengaruhi. Karenanya, teori-teori modernisasi tidak cukup digunakan untuk menganalisis berbagai dinamika masyarakat. Oleh karena itu, berbagai teori selain modernisasi, juga melibatkan teori etnografi, hermeneutika, teori interpretatif, dan sebagainya.

Di balik wataknya yang tenang, setiap masyarakat mengalami perubahan secara pelan namun pasti. Memasuki abad ke-20, sistem sosial masyarakat ditandai dengan munculnya bentuk-bentuk sosial yang lebih kompleks ditentukan dua proses kembar, yakni; di satu pihak, spesialisasi dan diferensiasi struktural, dan di pihak lain, mekanisme integrasi dan koordinasi sosial. Sejalan dengan kemajuan masyarakat, klasifikasi kerja di dalam masyarakat bertambah rumit, dan organisasi politik mereka bertambah luas dan rumit, serta partisipatoris. Ini semua mengakibatkan melemahnya ikatan-ikatan sempit kekeluargaan, kesukuan, keagamaan; menghilangkan potensi perpecahannya, 
serta menyediakan konsensus umum bagi tatanan sosial, kehidupan sosial, dan politik yang baru (Smelser, 1963: 352-374).

Studi tentang Islam dan Tengger sesungguhnya telah dilakukan oleh banyak sarjana, baik sarjana Barat maupun sarjana Indonesia sendiri. Studi Islam dan Tengger dimaksud dalam konteks yang lebih umum, yakni studi tentang Islam dan budaya lokal. Sejak awal, para sarjana Barat seperti Geertz, Hefner, Woodward, Mulder, Zaehner, Peacok, dan masih banyak yang lain telah meneliti relasi antara Islam dan budaya lokal (baca: Jawa). Kesimpulan dari para sarjana Barat dalam melihat "Islam Jawa" (tidak terkecuali relasi antara Islam dan budaya Tengger) melahirkan dua tesis atau pandangan utama; (1) Islam formalis dan (2) Islam subtansial.

Pandangan pertama diwakili oleh Geertz yang mengatakan bahwa masyarakat Jawa dianggap tidak sungguh-sungguh memeluk agama Islam. Kecuali hanya sedikit komunitas muslim di Jawa yang secara sungguhsungguh memeluk Islam sebagai sistem kepercayaan. Kelompok kecil ini dalam pandangan Geertz diwakili oleh para pedagang perkotaan yang telah mengalami proses modernisasi. Sebagian besar lainnya, masyarakat Jawa dalam menyakini Islam dianggap kurang serius. Islam sebagai sistem religi, dimaknai oleh Geertz dicampur aduk dengan sistem kepercayaan, tradisi, dan budaya masyarakat Jawa dari peninggalan tradisi dan budaya Hindu-Budha, bahkan sistem kepercayaan lama, yakni anismisme dan dinamisme. Geertz menyebut Islam ala Jawa ini disebutnya sebagai Islam sinkretis.

Pandangan Geertz ini memang dikritik oleh banyak sarjana Barat sendiri. Di antara sarjana yang mengkritik Geertz adalah Hogdson. Menurut Hodgson, Geertz kurang memahami tentang ajaran Islam sesungguhnya. Cara pandang Geertz sangat dipengaruhi oleh pola berfikir Islam modernis yang dianggap tidak bisa menggambarkan tentang dimensi Islam yang luas. Godgson menegaskan bahwa sistem kepercayaan Islam yang kompleks meniscayakan Islam mampu mengantarkan pada kejayaan masa lalu. Lebih jauh Hodgson menegaskan:

"Studi paling penting mengenai Islam di Malaysia (baca: Indonesia) adalah Religion of Java karya Clifford Geertz... Tetapi sayang, keunggulannya itu secara umum terganggu oleh kesalahan yang sangat sistematis. Karena terpengaruh oleh madzhab Islam yang beraliran syariat modern. Geertz hanya mengidentifikasi Islam dengan madzhab modernis dan juga menganggap segala sesuatu sebagai asli atau berlatar belakang Hindu-Budha sehingga dengan serampangan ia menamakan banyak kehidupan keagamaan umat Islam di Jawa sebagai "Hindu." Bagi orang yang memahami Islam, dengan datanya yang komprehensif, terlepas dari tujuannya, akan terlihat hanya sedikit yang bertahan dari masa lalu Hindu tersebut, bahkan, di pedalaman Jawa sekalipun. 
Hal ini memunculkan pertanyaan mengapa kejayaan Islam itu begitu sempurna" (Hodgson, 1974: 551).

Pandangan Geertz tentang Islam di Jawa memang banyak dianut oleh sekian sarjana Barat lainnya. Mulder misalnya, yang meneliti tentang Islam di Banyuwangi juga memiliki pandangan yang tidak jauh beda. Menurutnya, Islam di Jawa banyak dipengaruhi oleh tradisi Hindu yang sangat kuat. Bahkan, tradisi Hindu lebih dominan dari unsur-unsur Islam itu sendiri. Karena itu, pandangan ini melihat bahwa Islam yang tumbuh dan berkembang di Jawa tidak lebih dari sekedar klise atau sinkretis. Senada dengan Mulder, Peacock lebih ekstrim lagi. Menurutnya, Islam di Jawa tidak lebih seperti belantara gaib. Sama seperti Geertz, Peacock dalam studinya tentang Islam di Indonesia lebih dipengaruhi oleh pandangan kelompok Islam modernis. Bahkan, diketahui, pandangan Peacock ini ikut membentuk mainset keilmuan Geertz. Lebih jelas, Peacock mengatakan;

"...... Kita harus mengingat kembali konsensus umum dalam studi-studi etnografi, bahwa, pandangan dunia Jawa tradisional, karena tersusun dari kekuatan-kekuatan spiritual dalam berbagai bentuk dan citra, seperti kekuatan yang gaib, tempat-tempat keramat, ruh-ruh, dewa-dewa, guru-guru, dan aturan-aturan; dunia sinkretik Jawa adalah apa yang disebut Weber sebagai 'taman gaib' (garden of magic), sungguh belantara animistik" (Peacock, 1978: 43).

Beberapa sarjana Barat yang datang akhir memiliki pandangan lain dalam melihat Islam dan budaya Jawa. Tidak hanya mengkritisi pandangan awal, lebih dari itu, mereka memiliki pemikiran paradoks dengan yang awal. Woodward misalnya, membalikkan pandangan Geertz. Berpusat di Yogyakarta, Woordward berkesimpulan bahwa Islam yang dianut oleh masyarakat Jawa mencitrakan Islam yang autentik dan subtansial seperti ajaran Islam sejak zaman Rasulullah. Penerimaan terhadap tradisi dan budaya Jawa harus dimaknai sebagai eklektisme dan fleksibilitas ajaran Islam. Berbagai bentuk praktek ajaran Islam yang dipandang menyimpang oleh sekelompok orang lain sesungguhnya masih memiliki kaitan dalam tradisi Islam. Woordward merujuk dalam tradisi tasawuf, sufi, atau yang terlembagakan di dalam tarikat (Woodward, 1999: 25).

Woodward memang membagi masyarakat Islam di Jawa ke dalam dua kelompok besar. Dia menyebutnya dengan istilah Islam normatif dan Islam kebatinan. Islam normatif merujuk kepada sekelompok masyarakat Muslim di Jawa yang mengambil pemikiran-pemikiran modern yang berkembang di Timur Tengah. Gerakan-gerakan Islam yang dipelopori oleh Muhammad Abduh, Jamaluluddin al Afghani, Rasyid Ridho, dan Muhammad bin Abdul 
Wahab adalah prototipe dari Islam normatif ini yang juga berpengaruh di kalangan muslim di Indonesia dan Jawa khususnya. Sebaliknya, Islam kebatinan dirujuknya sebagai Islam yang dianut oleh sebagian besar masyarakat Jawa yang ditandai dengan akulturasi terhadap budaya Jawa.

Dua perspektif ini dapat digunakan dalam menganalisis terhadap dinamika relasi antara Islam dan budaya masyarakat Tengger yang diwakili dalam lokus penelitian ini, yakni masyarakat Tengger yang berdiam di Desa Ngadisari dan Sapikerep. Pemaknaan masyarakat Tengger terhadap Islam dengan watak dan coraknya yang mengadopsi budaya lokal, yakni budaya Tengger dapat dibaca dengan dua perspektif ini. Selanjutnya, akan diuraikan dua pandangan tersebut dalam memahami tentang pergulatan Islam dan tradisi Tengger bagi masyarakat yang berdiam di kawasan Tengger.

\section{Politik Identitas Masyarakat Tengger: Strategi Negosiasi}

Setiap masyarakat tidak dapat melepaskan diri dari pengaruh luar. Kehadiran Islam di satu sisi, dan dominasi kekuasaan pemerintah di sisi lain, mengubah banyak hal dalam sistem kehidupan masyarakat di Tengger. Sebagai cara defensif bagi masyarakat dalam merepresentasikan identitas diri mereka salah satunya melalui negosiasi. Negosiasi sendiri adalah bagian dari politik representasi. Cara seperti ini memang biasa ditempuh dengan berbagai kekuatan politik-kebudayaan yang cenderung minoritas. Metode negosiasi dalam prakteknya memang cenderung murah, dan efek resikonya relatif kecil jika dibandingkan dengan metode konfrontasi. Menyikapi hal ini beragam upaya dilakukan oleh orang-orang Tengger. Strategi itu antara lain;

a. Menerima Agama Formal secara Simbolik

Ketika agama formal, seperti Islam, dan Hindu masuk ke Tengger seperti "tamu" yang tidak mungkin lagi ditolak keberadaannya. Maka masyarakat Tengger menyikapinya secara formalis juga. Sebagian dari masyarakat Tengger menerima kebijakan negara yang mengharuskan mereka memeluk agama formal. Dipeluknya salah satu agama formal oleh orang-orang Tengger itu misalnya tertuang di dalam dokumen-dokumen kependudukan seperti; kartu tanda penduduk, surat kawin, surat ijin mengemudi, dan dokumen lainnya.

Pencatatan dan pencatuman agama ke dalam dokumen kependudukan ini tidak lebih sebagai klise saja bagi sebagian orang Tengger. Jalan ini mereka tempuh untuk memudahkan berbagai macam hal terkait dengan urusan pencatatan sipil sebagai warga negara Indonesia. Pemerintah Indonesia 
tidak mengakui Tengger sebagai agama formal. Dan hal ini berakibat serius bagi pengurusan dokumen kependudukan.

Cara ini mereka tempuh untuk menyelamatkan eksistensi kepercayaan mereka sendiri yang oleh kelompok masyarakat Tengger dalam kategori ini tidak bisa tergantikan oleh apa pun, namun mereka tak kuasa melawan kekuasaan negara. Walau secara formal memeluk Hindu atau Islam, tetapi ruang spiritual mereka sehari-hari masih menjalankan kepercayaan Budo Tengger.

b. Memisahkan Agama dan Adat

Sejak masa kekuasaan Orde Baru berlangsung, pemerintah hanya membolehkan lima jenis agama yang dianut oleh masyarakat. Tengger sebagai sebuah kepercayaan lokal tampaknya tidak masuk dalam kategori itu. Keharusan masyarakat Tengger untuk memeluk agama formal memaksa masyarakat Tengger harus mengatur strategi agar mekanisme adat yang telah berlangsung ribuan tahun tetap berjalan sebagaimana adanya. Untuk menyelamatkan tatanan adatnya ini, masyarakat Tengger membuat konsep pemisahan agama dan adat. Dalam konteks agama, mayoritas masyarakat Tengger beragama Hindu dan sebagian beragama Islam.

Berlindung di balik konsep adat sejak pemerintahan Orde Baru, maka masyarakat Tengger bisa merasa lega. Pemerintah hingga kini tampaknya tidak mempersoalkan dilaksanakannya nilai-nilai dan tradisi adat yang diwariskan oleh leluhur dari generasi ke generasi lainnya dan terpelihara hingga saat ini. Walaupun dalam pelaksanaannya, beberapa nilai-nilai adat itu menyesuaikan dengan beberapa praktik modernisasi. Misalnya saja, saat ini harus berbagi tempat ritual, antara ritual di sanggar pamujan dan ritual di pura. Padahal dalam perkembangan waktu saat ini, banyak sekali sanggar pamujan yang berubah fungsi menjadi pura. Untuk menyiasati hal ini, masyarakat Tengger tetap menyisakan ruang kecil untuk keberadaan sanggar pamujan, dan biasanya letaknya di belakang pura.

Pigeaud mencatat, di wilayah pegunungan Tengger pra-Islam pernah memainkan peran penting dalam peran-peran keagamaan yang didukung oleh negara. Di sini pernah menjadi pusat komunitas kependetaan, baik Siwa maupun Budha, serta sejumlah komunitas desa yang menyembah dayangdayang pegunungan (Pigeaud, 1962: 443-44). Dayang-dayang yang penting itu dihubungkan dengan Gunung Bromo. Di sekitar kawah Gunung Bromo, secara turun-temurun, masyarakat Tengger melakukan ritual keagamaan Hindu. Adat istiadat masyarakat Tengger yang dikaitkan dengan tradisi Hindu, oleh para sarjana Barat dikaitkan dengan dominasi kekuasaan Islam 
dengan runtuhnya Majapahit pada abad XIV. Hefner (1985:46), misalnya, menyebutkan, masyarakat Tengger adalah entitas kelompok warga Hindu yang melarikan diri dari Majapahit di era keruntuhannya dari kejaran kekuasaan Islam.

c. Memadukan Ritual Agama dan Ritual Adat

Sebagian besar orang Tengger memisahkan konsep dan pelaksanaan ritual agama dan adat, namun dalam beberapa kategori dan praktik tertentu dengan memadukan antara agama dan adat. Perpaduan ini terjadi juga sebagai strategi untuk melindungi praktik-praktik adat.

Hal ini mereka lakukan agar praktik pelaksanaan adat benar-benar lepas dari argumen-argumen agama. Beberapa pemuka Tengger memandang bahwa beberapa ritual di Tengger memiliki basis legitimasi agama yang cukup kuat. Dengan mengatur posisi seperti ini, sejatinya agama tidak memiliki cukup alasan untuk menyingkirkan nilai-nilai adat yang ada di Tengger. Dengan begitu, kekuatan agama formal akan membiarkan pelaksanaan ritual adat itu berlangsung tanpa memiliki pretensi untuk "memberadabkan" atau "mengagamakan" kembali nilai-nilai adat Tengger.

Hefner mencatat, tidak banyak wilayah Jawa yang menyimpan jejakjejak yang dapat dilihat dari sejarah Asia Tenggara yang kompleks seperti pegunungan Tengger. Sebagai bagian dari negara, Hindu-Budha yang berpusat di dataran rendah seribu tahun lalu, ia merupakan satu-satunya wilayah Jawa di masa modern ini yang masih memiliki tradisi keagamaan Hindu yang asli. Setelah kerajaan Hindu Majapahit runtuh pada awal abad XVI M, pusat-pusat kekuasaan di pulau Jawa ini bergeser ke Barat, ke keraton-keraton Islam di Jawa Tengah. Pengaruh kekuasaan berpusat di dataran rendah di wilayah pengunungan timur surut (Hefner, 1985: 49). Selama dua abad kemudian, politik dan agama telah mengisolasi orang Jawa pegunungan ini dari saudara-saudara mereka yang beragama Islam di sebelah barat.

Kenyataan ini memang membawa konsekuensi tertentu, di mana tarik ulur antara pemaknaan ritual dengan basis agama atau adat, bagaikan bandul yang terus mengayun. Bandul yang satu berada dalam garis ukuran adat, dan bandul yang lainnya dalam garis ukuran agama.

d. Menolak Agama Formal yang Tidak Bisa Integrasi dengan Adat

Selain memisahkan dan memadukan praktik ritual agama dan adat, orang Tengger pada umumnya menolak praktik agama yang tidak bisa berlaku moderat terhadap pelaksanaan ritual yang sesuai dengan adat istiadat. Islam, 
dalam hal ini, mereka pandang sebagai salah satu agama yang belakangan ini di beberapa desa dikembangkan untuk menjauhkan orang Tengger dengan nilai adat mereka sendiri.

Di saat hal ini terjadi, maka kebanyakan orang Tengger membangun konsep kewaspadaan atas praktik purifikasi agama. Walau harus diakui bahwa orang Tengger sendiri juga yang menjalankan keberagamaan seperti ini. Perlahan tetapi pasti mereka membuat gerakan untuk pemurnian nilainilai agama. Mereka yang disokong oleh pemuka agama dari luar memiliki obsesi untuk menjauhkan orang-orang Tengger dari nilai-nilai adat mereka yang telah lama ada.

Gejala purifikasi agama ini memang terjadi hampir di semua agama besar di dunia. Tidak luput itu juga menggejala di Hindu dan Islam yang berkembang di Tengger. Orang Hindu di Tengger membuat gerakan pemurnian kembali agama dengan menjadikan Bali dan India sebagai sentrumnya. Sebagian orang Islam di Desa Sapikerep juga melakukan hal yang sama pula. Orang Islam yang rata-rata pendatang baru di desa ini membuat target menjauhkan Islam dari pengaruh pengaruh adat Tengger.

e. Menumpang Program Pariwisata Pemerintah

Masyarakat suku Tengger tampaknya cukup diuntungkan dengan kebijakan pemerintah menggalakkan pariwisata, khususnya di Tengger. Sejak lama program wisata alam dan budaya dikembangkan oleh pemerintah. Melalui peningkatan sektor ekonomi, pemerintah pengembangkan program wisata ini. Secara ekonomi, program ini memberi dampak langsung dengan memberi tambahan pendapatan kepada orang Tengger. Selain itu, program wisata dianggap oleh orang Tengger bisa menjadi benteng dan tameng untuk tetap menjalankan adat mereka.

Memang dunia pariwisata hanya memandang bahwa nilai-nilai adat yang berkembang di Tengger sebagai sesuatu yang unik dan eksotis. Dunia pariwisata tidak mau melihat lebih jauh soal pergulatan orang Tengger dalam menjaga dan mempertahankan adat dan tradisi mereka. Dunia pariwisata kebanyakan berhubungan dengan mekanisme "having fun" bagi penikmatnya.

Namun dalam perjalanan waktu, dunia pariwisata dapat menjadi teman sejalan bagi orang Tengger untuk membentengi adat mereka. Di saat perjumpaan adat mereka dengan nilai-nilai agama menemui fase kritis yang sangat memungkinkan menghasilkan hubungan kalah-menang, maka dunia pariwisata menjadi teman koalisi bagi keberadaan adat Tengger. Dengan 
dijadikannya beberapa ritual Tengger sebagai paket program wisata, maka akan semakin banyak orang yang melihat. Dengan begitu, ancaman agama terhadap nilai-nilai adat dapat terhindar. Secara tidak langsung, negara juga berkepentingan untuk mendapatkan hasil-hasil ekonomi dari pariwisata. Di sisi lain, masyarakat diuntungkan dengan mempertahankan nilai-nilai lokal berupa mempertahankan tradisi lokal secara mandiri.

f. Mengangkat Tokoh Daerah dan Nasional sebagai Sesepuh Tengger.

Sebagai bagian dari politik representasi, masyarakat Tengger memiliki strategi defensif dalam mempertahankan identitas diri mereka. Di saat terjadi krisis dari back up kekuatan politik kepartaian, masyarakat Tengger masih memiliki cara untuk mendapatkan back up kekuatan politik. Dukungan politik itu diperoleh dengan cara melantik tokoh-tokoh nasional dengan beragam latar belakang, baik berkala nasional maupun daerah. Setiap bulan Kasada, orang Tengger mengundang dan meminta tokoh dari pejabat pemerintahan, anggota DPR atau tokoh populer lainnya untuk menjadi sesepuh Tengger.

Menurut dukun-dukun Tengger, para tokoh itu dilantik sebagai sesepuh Tengger dengan harapan mereka dapat memberikan kontribusinya bagi kemajuan komunitas Tengger. Tradisi pelantikan sesepuh Tengger ini telah lama dijalankan. Bahkan saat koordinator dukun masih dipegang oleh Alm. Soeja'i, banyak dari kalangan menteri, gubernur, dan bupati yang menjadi sesepuh Tengger. Timbal balik di antara tokoh-tokoh yang dilantik menjadi sesepuh Tengger itu beberapa di antaranya secara nyata bisa dirasakan oleh orang Tengger. Berbagai proyek pembangunan yang digulirkan di Tengger melebihi pembangunan di kota Kecamatan Sukapura. Padahal antara kawasan Tengger dengan Kota Kecamatan Sukapura relatif jauh. Akan tetapi, pembangunan di Tengger lebih spektakuler jika dibandingkan di kota kecamatannya.

g. Membangun Mitos-mitos

Di balik wataknya yang sederhana dan terkesan diam, masyarakat Tengger dalam merepresentasikan politik identitas mereka, memiliki banyak strategi lain. Berbagai cerita mitologi sering dipergunakan oleh orang Tengger untuk menggambarkan pergulatan mereka di masa lalu. Cerita-cerita mitologi ini memang menjadi dokumen sejarah bagi orang Tengger bagi generasi selanjutnya. Melalui cerita mitologi itu pula, orang Tengger generasi modern membangun sistem kewaspadaan terhadap 
berbagai kemungkinan yang mengancam terhadap eksistensi adat-istiadat, tradisi, dan budaya Tengger.

Berbagai kisah dan cerita mitologi sering dijumpai hampir di setiap ritual tradisi dan budaya Tengger. Kisah mengenai ritual Karo sebagaimana yang dituliskan oleh Hefner setidaknya menggambarkan fenomena ini. Di dalam kisah itu digambarkan pertarungan antara utusan Nabi Muhammad dengan utusan Ajisaka dalam mempertahankan perintah keduanya. Kisah ini tentu untuk melambangkan berbagai kejadian yang berjejak pada masa mitologi ini muncul.

Dugaan Hefner, mitologi ini muncul pada masa peperangan kekuasaan antara Majapahit dengan Demak dan terus berkelanjutan peperangan antara kerajaan-kerajaan Islam di Jawa dengan berbagai kekuatan lokal non-Islam. Cerita simbolik peperangan antara utusan Nabi Muhammad SAW dan utusan Ajisaka tentu berjejak pada kisah peperangan antara Islam dan non-Islam, termasuk di antaranya Tengger. Kini cerita seperti ini dalam konteks Karo memang relatif tidak dipahami oleh generasi Tengger saat ini. Tafsir atas Karo tentu sudah bergeser. Perebutan dan pemaknaan Karo menjadi potret betapa dinamisnya orang Tengger melihat konteks.

\section{Relasi Islam dan Budaya Tengger: Formalitas vis-à-vis Subtansial}

Watak "Islam Jawa" di satu sisi dengan tradisi lokal yang telah tertanam sejak lama dalam kehidupan masyarakat Jawa menunjukkan dialektika secara harmonis. Dialektika keduanya, di kalangan para sarjana menghasilkan dua kesimpulan yang saling bertolak belakang. Seperti telah disinggung di awal, dialektika antara Islam dan budaya lokal menghasilkan dua kesimpulan berbeda; Islam sinkretis dan Islam kultural (subtansial). Dengan argumentasi masingmasing, pendapat pertama telah diuraikan pada pembahasan sebelumnya. Di bawah ini akan diuraikan pendapat kedua yang melihat, antara Islam dan budaya lokal menunjukkan dialektikanya tanpa menghilangkan unsur penting masing-masing.

Warna maupun corak keislaman yang dipraktikkan oleh minoritas masyarakat Tengger di tengah mainstream masyarakat Tengger yang Hindu, sesungguhnya tidak ubahnya seperti masyarakat muslim Jawa lainnya. Bagi Woodward, kehidupan keagamaan masyarakat muslim Jawa sepintas lalu terasa bercampur aduk dengan tradisi lokal peninggalan tradisi HinduBudha. Dalam risetnya yang mengambil Keraton Yogyakarta, Woodward menunjukkan fenomena tersebut. Keraton Yogyakarta, dalam spektrum 
luas, dimaknai sebagai pusat kosmologis tradisi dan budaya masyarakat Jawa. Namun demikian, Woodward tidak seperti kesimpulan Geertz yang menegaskan adanya sinkretisme antara Islam dan budaya Jawa, terutama tradisi Hindu-Budha. Dalam pandangan Woodward, tradisi Islam di Jawa (Keraton Yogyakarta) menunjukkan kepiawaian Islam dalam mempengaruhi masyarakat Jawa. Woodward berpandangan, bahwa, antara Islam dan tradisi Jawa tidak lain hanya sekedar akulturasi budaya sebagai strategi dakwah (Woodward, 1999: 123-34). Akulturasi budaya tidak lantas menghilangkan unsur dasar dari ajaran Islam itu sendiri.

Salah satu kunci dalam memahami pandangan Woodward terhadap Islam Jawa adalah menempatkan tasawuf atau sufisme dalam memahami Islam. Watak dasar sufisme dalam penyebaran Islam ditandai dengan penghormatan terhadap budaya lokal. Seperti terjadi di Jawa pada umumnya, Islam pada periode awal perkembangan di Jawa, bahkan hingga saat ini, masih ditandai dengan penghormatan terhadap tradisi dan budaya lokal. Fenomena sama dapat digunakan dalam melihat relasi antara Islam dan Tengger.

Dalam praktek keagamaan yang ditampakkan oleh komunitas muslim di area penelitian ditandai dengan beberapa hal mendasar; Pertama, eksistensi dukun sebagai kepala adat, bahkan, tokoh agama Tengger, masih dilibatkan dalam setiap perayaan keagamaan Islam. Kedua, upaya-upaya adat seperti Karo, Kasodo, dan lainnya, masih diikuti oleh umat Islam. Selain itu, ritual-ritual ini digunakan sebagai media dakwah Islam. Ketiga, penghormatan terhadap makrokosmos yang disimbolisasikan melalui Gunung Bromo juga masih tetap dipertahankan oleh komunitas muslim di Tengger.

Islam dalam konteks tasawuf tidak harus ditempatkan dalam perspektif syariah saja. Tasawuf banyak mengajarkan tentang subtansi Islam itu sendiri, yakni akhlakul karimah, keadilan, harmonisme alam sebagai wujud Tuhan, dan masih banyak lagi. Seluruh konsepsi Islam demikian, dalam pandangan tasawuf tetap disandarkan kepada al Quran, hadits, serta praktik kehidupan Muhammad yang selalu diwarisi oleh umat Islam melalui para guru-guru sufi secara turun-temurun. Tasawuf meyakini bahwa Rasulullah dalam mengajarkan Islam selalu menghormati warisan budaya umat di masa lalu tanpa harus menghilangkannya sama sekali.

\section{Simpulan}

Masyarakat Tengger dikenal sebagai entitas masyarakat yang kuat dalam mempertahankan tradisi dan budaya. Di tengah proses perubahan panjang 
secara berkelanjutan, masyarakat Tengger terbukti tidak bergeming dalam memegang erat tradisi yang diwarisi dari para leluhur secara turun temurun. Berdasarkan atas analisis di atas, relasi antara Islam, kekuasaan, dan Tengger dalam mempertahankan serta merepresentasikan tradisi dan budaya mereka dapat dikategorisasikan ke dalam dua asumsi sebagai berikut: pertama, masyarakat Tengger dalam relasinya antara Islam, kekuasaan, dan ke-Tenggeran mereka, memiliki sikap fleksibel, adaptif, dan lentur dalam menerima perubahan yang datangnya dari luar. Kekuasaan pemerintah yang bersifat mengikat dan kehadiran Islam dipandang sebagai ancaman. Tetapi, dengan strategi mereka, masyarakat Tengger mampu beradaptasi terhadap keduanya secara fleksibel pula. Fakta ini seolah meneguhkan bahwa relasi antara Islam dan Tengger diasumsikan sebagai hubungan yang pura-pura. Penerimaan masyarakat Tengger terhadap Islam dimaknai sebagai hubungan formalitas. Islam dan masyarakat Tengger dimaknai sebagai Islam formalis atau Islam sinkretis seperti analisis sarjana Barat yang diwakili oleh Geertz; kedua, di balik watak masyarakat Tengger dalam menerima tradisi dan budaya dari luar yang terkesan fleksibel, bukan berarti mereka tidak menerima dengan sungguhsungguh. Kehadiran Islam bagi sebagian masyarakat Tengger sesungguhnya terserap secara substansial yang dibingkai melalui akulturasi budaya lokal, yakni tradisi dan budaya Tengger. Fenomena ini tidak ubahnya seperti pengaruh Islam di Jawa pada umumnya yang ditandai dengan penghormatan terhadap tradisi Jawa. Pendekatan tasawuf menjadi kata kunci dalam memahami realitas ini. Woodward adalah salah satu sarjana Barat yang mewakili pandangan ini. Menurutnya, di balik penghormatan terhadap tradisi dan budaya lokal, nilainilai Islam secara subtansial tetap menjadi pegangan utama.

\section{Daftar Pustaka}

Hefner, Robert W. 1985. Hindu Javanese: Tengger Tradition and Islam. Princeton: Princeton University Press.

Hefner, Robert W. 1990. The Political Economy of Mountain Java: An Intepretative History. California: University of California Press.

Hefner, Robert W. 1999. Geger Tengger: Perubahan Sosial dan Perkelaian Politik. Yogyakarta: LKiS.

J. Peacock. 1978. Muslim Puritans: Reformist Psychology in South-east Asian Islam. Berkeley: University of California Press. 
M. Hodgson. 1974. The Venture of Islam: Conscience and History in a World Civilization, Volume 3. Chicago: University of Chicago Press.

Mark R. Woodward. 1999. Islam Jawa: Kesalehan Normatif versus Kebatinan. Yogyakarta: LKiS.

Moleong, Lexy J.. 2002. Metodologi Penelitian Kualitatif. Bandung: PT Remaja Rosdakarya.

Neil J. Smelser. Mechanism of Change and Adjustment to Change. Garden City, N.Y: Natural History Press.

T G. Pigeaud. 1962. Java in Fourteenth Century: A Study in Cultural History, Volume 5. The Hague: Martinus Nijhoff.

Usman, Husaini dan Purnomo Setiadi Akbar. 1996. Metodologi Penelitian Sosial. Jakarta: Bumi Aksara.

el Harakah Vol.17 No.1 Tahun 2015 